University of Wollongong

Research Online

Faculty of Social Sciences - Papers (Archive) Faculty of Arts, Social Sciences \& Humanities

2015

Mingadhuga Mingayung: Respecting Country through Mother Mountain's stories to share her cultural voice in Western academic structures

Anthony D. McKnight

University of Wollongong, anthonym@uow.edu.au

Follow this and additional works at: https://ro.uow.edu.au/sspapers

Part of the Education Commons, and the Social and Behavioral Sciences Commons

Research Online is the open access institutional repository for the University of Wollongong. For further information contact the UOW Library: research-pubs@uow.edu.au 


\title{
Mingadhuga Mingayung: Respecting Country through Mother Mountain's stories to share her cultural voice in Western academic structures
}

\author{
Abstract \\ The cultural invasion of Yuin Country in Australia did not only colonise the Yuin peoples and Yuin Country \\ itself, it contributed to non-Aboriginal peoples' continual colonised journey of disconnecting self from \\ Mother Earth. Cultural Awareness is a term and process driven by western theories informed by the \\ colonial dualism that functions on separation and differences. Tripartation is a term to assist in a \\ decolonisation and more importantly a re-culturalisation process to place Yuin Country and aligning \\ Stories back into focus for all peoples attached to Yuin Country. Tripartation challenges western dualities \\ to create a philosophical space, place and reality in Aboriginal dualities for non-Aboriginal peoples to find \\ similarities and connections through Stories to build respectful relationships with Aboriginal peoples, Yuin \\ Country and importantly self. Mingadhuga Mingayung (My Mother Your Mother) focus is on identifying \\ whose stories that can conjoin similarities through Stories to guide non-Aboriginal peoples in Yuin Ways \\ of knowing, learning and behaving with Country.
}

\section{Keywords}

academic, western, voice, cultural, her, share, stories, mountain, mother, country, respecting, mingayung, structures, mingadhuga

\section{Disciplines}

Education | Social and Behavioral Sciences

\section{Publication Details}

McKnight, A. (2015). Mingadhuga Mingayung: Respecting Country through Mother Mountain's stories to share her cultural voice in Western academic structures. Educational Philosophy and Theory, 47 (3), 276-290. 
Viewing and Speaking Ourselves through English: Setting the scene for a reculturalised and decolonised approach for non-Aboriginal people to be sung into Yuin Ways of Knowing

My voice is just as important as any. Whether you listen or not is your priority not mine.

Gulaga gives us our stories of Creation (Harrison 2009, p. 19).

The purpose of this article is to introduce and present a Yuin ${ }^{1}$ (Aboriginal Nation) living body of knowledge pedagogy that provides experiences for nonAboriginal peoples in Yuin Ways of Knowing, Learning and Behaving. The Yuin Ancients and Ancestors have provided (sung up) this innate approach that is called Mingadhuga Mingayung (My Mother Your Mother). Uncle Max Dulamunmun Harrison, Yuin Elder and Lawman, who holds these Stories of Country has given me permission as a Cultural man and academic to share my teachings in connecting peoples to Country. The particular Yuin Stories that inform this reinstatement of Yuin Knowing, Learning and Behaving, reveals ancient ways to building a respectful relationship with Country. Imperatively Mingadhuga Mingayung plays a role in Indigenising decolonisation to a reculturalisation process of a colonised Country. The re-culturalisation process was born (and has always existed) from Gulaga (a significant Mountain on the far South Coast of New South Wales) through the Elders' knowledge. The Elders have maintained the Mountain's integrity and purpose by passing on the Stories that have remained the same since its own creation (Creation Dreaming). Gulaga, Mingadhuga Mingayung hosts and teaches non-Aboriginal peoples Yuin Stories to know how to learn from the source of Yuin knowledge: Yuin Country. Central to this approach is how Gulaga's 'silent' voice and powerful energy guides the individual's experience to examine self so that connections can occur in respectful relationship with Country.

Respectful relationships are at the heart of Mingadhuga Mingayung which is the encompassing name of the approach being presented in this article. The term Cultural Awareness (CA) is not the focus of the article and will not be described in depth. The focus is on Minghadhuga Mingayung and not on a response to notions of CA that originate from the coloniser. This article will articulate the Yuin cultural process that

\footnotetext{
1 Yuin Country "Extends from the Snowy River in the South to the escarpment of Wollongong, our northern boundary, and then out to the Southern Tablelands. Our Country follows the coast down and into Victoria” (Harrison and McConchie, 2009, p. 15)
} 
decolonises the western dualistic environment in which Aboriginal and non-Aboriginal people endure today. The Mingaghuga Mingayung approach sings in Country to help non-Aboriginal people to hear Gulaga's silent voice to reduce western theory's colonial obstructive influence to Yuin relationships. The sweeping away by song of the colonial web of complexity and the difference barrier provides a space for the living estuary of Country as Mingadhuga Mingayung to function in the heart and spirit of non-Aboriginal peoples. Mingadhuga Mingayung deriving from Country provides Stories, not western colonising theory, to identify similarities for connections to form between nonAboriginal peoples and Yuin Country. The Mingadhuga Mingayung approach highlights Tripartation, a spiritual passageway between dualistic terms by decreasing the influence of colonisation in action: western dualistic thinking of difference. Mingadhuga Mingayung contributes and continues the protection and taking care of Country: Mother Earth, Father Sky, Grandmother Moon and Grandfather Sun by Yuin peoples, whereby we can guide non-Aboriginal people to understand and respect our ways of knowing, learning and behaving. Mingadhuga Mingayung creates an opportunity for nonAboriginal people to see Country and take responsibility for their own actions in the relationship with Mother Earth.

\section{A closer consideration of the Western dualism and My Story}

'At the beginning, before Daruma, the Great Spirit, created Tunku and Ngardi, there was only oneness' (Umbarra video 1996 cited in Rose, James \& Watson 2003: 41).

Yuin knowing is instilled in oneness, where everything is connected. The western dualism placed on Yuin Country by the coloniser separates being into a hierarchical opposition, resulting in a westernised manifestation of culture that creates a way of being in the world premised on separation. This dualism has the effect of corralling the patterns of connections in Yuin culture into a hierarchy of male dominated order. Western dualism is colonisation of the spirit in action through separation, as it places Country, in which I am, as subservient but connected, to western intellectualised culture. The western dualism replaces Country with nature into a negative and subjugated sphere. The western cultural worldview that cannot see or hear Country in oneness of spirit estranges the relationship with the self as Country. The following quote from Plumwood (2002) is utilised to assist the reader in unpacking the consequences and the cultural blindness of the dominant western dualism through an examination of the relationship between the human self, nature and Country as self. 'Human/nature dualism... is a system of ideas that takes a radically separated reason to 
be the essential characteristic of humans and situates human life outside and above an inferiorised and manipulable nature' (p. 4).

The dualistic binary system placed onto Yuin Country is a 'legacy' from the 'Western Enlightenment and progression' that imposes unequal and disconnecting relations. This foreign dualism has successfully and unsuccessfully attempted, and still attempts to disrupt the relationship between Umbarra the Black Duck (Yuin Nation 'Totem') with its peoples, generating deception and disconnections in relationships. Western notions of dualism place culture/nature in a binary relationship to manoeuvre Mother Earth (Country) as subordinate to western male culture, logic and reasoning. This imperialist/industrial creation of being 'man' separate from nature as a 'cultural reality' is explored by Levinas (2006) in relation to the western progression away from self:

Culture can, first, be interpreted - and this is the privileged dimension of the Greco-Roman West (and its possibility of universalization) - as an intention to remove the otherness of Nature, which, alien and previous, surprises and strikes the immediate identity that is the Same of the human self (p. 155).

The removal and replacement of Country by nature is a problem inherent in the foreign dualism. The hierarchical dualistic binaries of unequal relationships position and privilege Western males through the detachment of their inherent connections in male/female, culture/nature, reason/emotion, sun/moon and European/Aboriginal relations. These male relations of power organise what counts as knowledge to specify what is of value in culture to mistreat, and what to honour. From an eco-feminist position Plumwood (2002) states: 'The colonising task is to make the land accommodate to us rather than we to it, leading to the rejection of communicative and negotiated ecological relationships of mutual adaptation in favour of one-way relationships of selfimposition' (p. 18). Plumwood's quote provides a stepping-stone to examine the cultural invasion of Yuin Country that suppressed Yuin knowing, learning and behaving. This cultural 'invasionist' reality for Yuin peoples was the imposed implementation of the western dualistic thinking and disconnecting action of being and behaviour. The western dualistic thinking places our Yuin culture as oppositional and 'othered', and consequently manipulated Yuin relationships into a competing cultural authority to the 'dominant' invading culture. This provided the false justification of implanting a foreign self-fulfilling culture with a perpetual purpose of cultural removal and replacement of 
Yuin cultural relationship to oneness. While this has been a dominant influence, as Yuin culture still exists, how cultural invasion is understood and its effects have to be questioned.

Freire (2000) writing on cultural invasion provides an opening for discussing the western cultural semantics of language in understanding the experiences of invasion to expand upon dualistic realities/unrealities. Freire (2000) states:

Cultural invasion is on the one hand an instrument of domination, and on the other, the result of domination. Thus, cultural action of a dominating character (like other forms of antidialogical action), in addition to being deliberate and planned, is in another sense simply a product of oppressive reality (p. 154)

Whilst the cultural invasion of Yuin Country occurred it did not remove the reality of oneness in the spirit world. However, the Yuin peoples understanding of the spiritual world has been informed (and may continue to be) by the colonial duality and subsequently corrupted by the English language. The invasion is an oppressive reality in the human realm, therefore spiritually as well, as the invaders removed Aboriginal people from Country by treating us like a 'selfish miner's' concept of Country ${ }^{2}$. However although some Yuin people were oppressed by this white reality it does not mean the Yuin reality of our Yuin dualism of 'two in oneness' was totally suppressed.

If the reality (of invasion) did not occur but only in memory, then the oppressed can connect or reconnect to self. This accentuates the Yuin cultural mindset to maintain a non-oppressed worldview. The disconnecting pain caused by oppression can deepen 'belonging in responsibility'. The 'being oppressed but not' provides the opportunity for taking care of self (which also means the responsibility of taking care of Country in the pre and post invasion reality). English language with the spirit of Country can be intentionally incorporated in Mingadhuga Mingayung to re-culturate non-Aboriginal and Aboriginal people as self into Country to be human. The Yuin reality of culture can exist without the spoken/written (English) language as the real communication of Yuin culture is done in silence. In Mingadhuga Mingayung the colonial cultural invasion that includes the English language reality is reduced, by the sharing of Stories in our cultural framework. Country / Yuin culture doesn't need English to exist; it can 'read' memory,

\footnotetext{
${ }^{2}$ This analogy emphasises that Country is deeply spiritual and includes all entities that make up Country. No entity is devoid of spirit and therefore everything is living including what miners take from the ground. It is like taking out your own liver when you remove iron ore.
} 
emotion and the behaviour of the body and spirit. Western dualisms being solely based on the human interaction of intellect, in communication via spoken and written language and depending on a hierarchical power relationship is oppressive and blocks spiritual exchanges.

Significantly, via the above approach it is possible for the oppressed/oppressor reality to be taken back to self in spirit, thereby, placing the human self, back into Country by recognising Country as self. This dance with the song of Country stomps out the corruption in spirit. Stepping out of the duality of oppressor/oppressed into a Country centred reality would mean the non-Aboriginal and Aboriginal reality of invasion that doesn't exist, but does, is to be forgiven; for healing self. This issues of the oppressor is taken up by Freire (2000), who points out the experience of the oppressor and oppressed:

To renounce invasion would mean ending their dual status as dominated and dominators. It would mean abandoning all the myths which nourish invasion, and starting to incarnate dialogi-cal action. For this very reason, it would mean to cease being over or inside (as foreigners) in order to be with (as comrades). And so the fear of freedom takes hold of these men. During this traumatic process, they naturally tend to rationalize their fear with a series of evasions (p. 156).

The above quote is used not to renounce invasion but to take note of its reality in the 'day to day' pitfalls and fears of the oppressor and oppressed establishing Yuin relationships. Renunciation and fear may fit in Freire's duality but placing Country as the centrepiece of the reality, the fear would be a fear of looking and being self. If looking at self and being is freedom, then a question can be posed: why rationalize self when you can heal with all participants as self-existing as Country? This is a key point in Mingadhuga Mingayung. Here the duality reality means that not everyone is ready to heal and enjoy the discomforts that have replaced the reality of being one with Country. To simplify and present this deep knowledge, it can be explained that Yuin peoples wait by providing Stories to share, so people can make their own decision to find self to reculturalise (re-human) with Country. This patient and time attentive approach is taken as the English language in policy is controlled by imperialist law. Mingadhuga Mingayung invites organisations/institutions, where western cultural awareness exists in policy, and individual people to pull down what can be conceptualised as 'policy fences' on Country and work with us to bring the Stories back to the surface with 
paralleling Stories of healing and Country; this reorients emphasis to Spirit and not 'language'.

Mingadhuga Mingayung contributes to the healing of the colonial dualism placed on all peoples and other life forms that have been othered (for example, birds, rocks, knowledge, lore, law and knowing) by male dominated dualistic thought that exist on/in Yuin Country. 'Country as Yuin' and the human as Country are removed and masqueraded in colonising discourses that cannot conceptualise anything beyond western dualistic terms. Since colonisation we as Aboriginal people/Country have been examined in theory of difference and separation in academia. A chapter of my Story is to share what I am currently 'seeing' as understanding Yuin culture when culture is sung/explored in academia.

\section{Tripartation}

As a starting point to a different approach and process that recognises Yuin ways of knowing, learning and behaving through a Yuin 'there is always two' in connection, rather than the dualism of Western thinking, I am proposing a notion of Tripartation. Tripartation offers non-Aboriginal people a place and space for spirit to be revealed within the duality through Yuin Stories, so self can connect to the Stories of Country.

Tripartation's purpose is to reduce the influence of the slash (/) in the western duality. This is not to dismantle, but rather to bring about a greater focus on the Aboriginal duality of oneness and not separation. While I use Tripartation, an 'English language' term, to describe an Aboriginal re-instatement viewpoint of duality inbetween the western duality and the Yuin 'there is always two', it is necessary to note its limitations. The term Tripartation does not create three distinct characters to the duality, for example woman/Country/man. Country is consisting of Mother Earth, who births the human woman and man, with the invisible umbilical cord still remaining to connect them back to her and to each other. Tripartation does not totally describe a Yuin meaning(s) and action(s), but it is a word to initiate peoples' thinking around its purpose. I have selected the western word Tripartition because it means threefold, and I have adapted the term to demonstrate Country as part of the Aboriginal self and vice versa. This places non-Aboriginal people into our worldview that they too come from Country originally, another place in the world, as all life is born by Mother Earth that is Country. 
The western interpretation of their dualism attempted to remove Country on all levels of being and this includes a de-emphasis of the spiritual embodiment of Country. In seeking to avoid such serious omissions, Tripartation recognises the slash in the western dualism but matches and reduces the slash's power. The paradox being, because Tripartation opposes the slash their relationship exists in a duality. Connection however can be achieved as the slash is reflected in the two dualisms that exist with its own dualism of slash and Tripartation. The third fold is the place of conjunction when the two dualisms parallel and reflect each other with the spirit of Country as its core. The Tripartation and slash reflection is at first used to try and explain the spiritual Storying concept of Country instead of the focus totally being on intellectual theory, connected to the colonial dualism. Mingadhuga Mingayung places Country as Story to demonstrate the slash's separating influence, at the same time inviting Tripartation to occur.

Country is most notably absent in current western CA practice. This is because while Country may be a part of the CA training, it does not inform the process. NgaraMinga ${ }^{3}$

"My voice is just as important as any, whether you listen or not is your priority not mine".

Listening and responding to Country is being respectful as Country provides us with everything we need including knowledge. The Yuin reciprocal responsibility is to take care of Country with 'our' knowing. WCA does recognise Country on a physical level, but Country as teacher remains limited because the restriction maintained by western dualistic theory, policies and commoditized economic influence in which Aboriginal people are allowed to function. Remembering Country is Self and Self is Country, Black (2011) provides an example of how Country is restricted on two levels; firstly by non-Aboriginal and Aboriginal people working in the Western system even though they demonstrate a general awareness of our achievements in society. Secondly the ways in which Aboriginal achievements are recognised in Western system restricts recognition of what is important to [maintaining] Country.

They never say the best and brightest lawyers are the senior law people of the Aboriginal tradition. Nor do they recognize their healers as the brightest in the medical field. The ideal role models for our youth are

\footnotetext{
${ }^{3}$ Ngara- Minga: listening, to really hear Mother.
} 
sportspeople, not Aboriginal people who care for the land and are expert hunters or gatherers with an abundance of ecological knowledge (p. 352).

Responding to this point, Tripartation can be understood as a term that has been created to give recognition to and share the gift from Country: Spirit. At the same time, it can point out the continual corrupting nature of Western dualism that masks Spirit as Country: Tripartation removal. This is because the human intellect has the capacity to disguise spiritual connectedness on all levels of the mind, body and spirit. Against such effects, Tripartation in the context of Yuin ways of learning is to place the Spirit of Country back into dualistic thinking; with the threefold element forever present.

\section{Singing up a Story of Pedagogy to Hear Country and Similarities with our Eyes}

In Yuin ways of knowing, learning and behaving we must listen to Minga (Mother) speak to us without voice so we can see her Story through the wisdom of the Elders. The Mingadhuga Mingayung approach is one way in which the legacies of our Ancients are held to maintain culture. Storying is the 'legacy pedagogy' that is passed on to the next generations to be 'held'. As Uncle Max Harrison (2008, personal teaching) describes 'I must give it (the Stories) away to hold it (the Stories)'. The teaching of the correct Stories from Country is the responsibility of the holders of Story. Importantly the beholders to the Story have an obligation in the learning process as well, as respect is shown in many varying (culture specific) forms. The silence while on Country while listening and viewing the Story(s) provides the depth in meaning, placing the responsibility on the viewers of the Story to feel the Story. Archibald (2001) discusses an Aboriginal pedagogy as 'Storywork2' through her experience with her Canadian First Nations cultural teacher:

Simon told many of his life experience stories using this method, which is pedagogy. I called this pedagogy Storywork2 because the engagement of story, storyteller, and listener created a synergy for making meaning through the story and making one work to obtain meaning and understanding (p. 1).

Aboriginal ways of learning are sustained by the 'legacy pedagogy' that coincides and exists within the Stories, and pedagogies such as 'Storywork2'. The 'legacy pedagogy', when placed in a written form in academia, only has the potential to take place in the mind of the reader to provide an intellectual interpretive picture. This is 
where the crux of learning lies or does not lie, for Mingadhuga Mingayung is about connecting, respecting and taking care of Country within the whole 'pedagogy' of two bodies. One 'body' is the human, the other 'body' is the Mother, that means we are one in the same. The connecting scripts in the body of the Story are there to see if the pedagogy is in 'transcription'. The viewer of the Story transcribes with Country the meaning they need at that moment in 'time' to help in their own self-healing of connecting to Country and themselves.

The 'transcription' to re-culturalisation within and outside of the self, alongside 'decolonisation', is one of the essential aims from the Mingadhuga Mingayung Story(s). The reinstatement of 'legacy pedagogy' in the enhancement of Aboriginal approaches is absolutely necessary to enact Tripartation. Transcription and legacy pedagogy are buried deeply and infused throughout the body of Country and bought to the surface by the Stories that are held by the pedagogical Story that is the Aboriginal circular platform of connectedness. The bonding agent of 'belonging in behaviour' is through the legacy pedagogy, triggered by Elders of Lore through Country's Stories.

Porr and Bell (2012: 167) emphasise the attachment Ngarinyin have to 'nature' by presenting a Story from her (Bell's) partnership with Elder, David Mowaljarlai:

... the sun is coming up, with that glow that comes straight away in the morning. The colour comes towards me and the day is waiting. You have a feeling in your heart that you're going to feed your body this day, get more knowledge. You go out now, see animals moving, a tree, a river. You are looking at nature and giving it your full attention ... Your vision has opened you and you start learning now. When you touch them, all things talk to you, give you their Story ... (Mowaljarlai and Malnic 1993, p. 53 quoted in Porr and Bell 2012, p.167)

In the above quote Porr and Bell (2012) demonstrate how Mowaljarlai reveals Ngarinyin ontology, the means by which their epistemology is developed: 'He listens to the day, attributes nature with the ability to communicate, and claims living relationship with all elements and processes within his habitat' (Porr and Bell 2012, p. 168).

Many Aboriginal people live in both 'Worlds', Aboriginal and non-Aboriginal; living in the tension caused by being in the present and being in the non-Aboriginal context of progressing forwards. Non-Aboriginal people are invited to live vice versa, to live in the now with Country, which is a purpose of Mingadhuga Mingayung. Legacy 
pedagogy applies to every individual as each individual comes from a Country somewhere in the world. The world is full of connecting cultural and human Stories that build connections and belonging to Country. The connections derive from where your ancestors are from, to where you live today and in the future. Country is then pedagogy that takes the form of various non-dialectic stimuli and is deeply spiritual.

Many non-Aboriginal peoples' identities are linked to the country now known as Australia however the western dualism connects them to enjoying the view of 'Australia', not seeing Country as placing them into identity. In Yuin ways of knowing, learning and behaving, you are placed by Country into the networks of reciprocal relationships. Birrell (2006) after years of learning from Yuin Country states that she came, 'From a place of disembeddedness and disembodiment, my journey has moved into embeddedness and embodiment' (p. 286). Learning to 'see and feel' Yuin Country through Country's Stories, Birrell, through working with Aboriginal Elders, disrupted the colonial dualism. This connects to the point made by Uncle Max, that 'to get people to learn and to understand is to look at the similarities, and not the differences. All the similarities are there in all the cultural Stories - it is global, there are similarities globally' (Uncle Max Harrison quoted in Birrell 2006, p. 111 and Personal Teaching 2011). In this way the binary concept that holds polarity together can be decolonised by adding the third and life giving essence of Spirit. As spirit exists in Country, is Country, we have to listen and see how this can 'transpire' in the human world.

The polarity of non-Aboriginal and Aboriginal peoples is connected or relational if you examine and listen to Mother Earth. People may experience learning from Country differently, but the knowledge is from the same 'womb'. For example a small stem has polarity and depending upon which is closest to the ground will form the base and take root, while at the other end, it will shoot. Both ends are as important as each other to maintain life of itself and everything else as the stem is 'inspirited' into oneness. Shifting the focus onto similarities, with difference being examined through a relational discourse, will enhance the re-culturalisation of the Yuin dualism. This will contribute to the decolonisation of the western dualisms nailed on Yuin Country. Enhancing the planting of 'progress into the re-connection' of Country will limit the corruption of the segmentation force of difference, to help us see Tripartation.

The Legacy Pedagogy and Tripartation Relationship Strands of Mind, Body and Spirit in One 
The following description of the legacy pedagogy correlates to the identity of Tripartation and the Story of paralleling together. In the account below a number of scientific metaphors in relation to living cells are used to demonstrate the holistic Story of legacy pedagogy synonymous with Mingadhuga Mingyung. This explanation of the Mingadhuga Mingayung Tripartation script via a three-stranded helix will assist in solidifying how points of cultural intersection can accrete into relatedness with each other. Equally the application of the Yuin cultural context in understanding the 'weaving' of the three strands into the helix in legacy pedagogy is another fundamental feature of this explanation.

The sharing of our lineage of legacies is the first strand, represented by what I call the mitochondrial aspect of the 'Minga' helix. The Stories and pedagogy of the Ancients provide the energy of the Mingadhuga Mingayung approach. Mitochondria have a traveling folding circular makeup, as well as the Stories and pedagogies that produce a 'usable' energy for the human 'cell'. Furthermore, taking care of Country, teaching and belonging in behaviour through narrative all coagulate together to formulate the first strand; this is a very personal matter for my ancestors and me. Aboriginal people find it difficult to remove the emotional and spiritual elements in human research or Storying as Lee Maracle (1992) shares, 'It takes a lot of work to delete the emotional and passionate self from Story, to de-humanize Story into "theory." So we don't do it. We humanize theory by fusing humanity's need for common directiontheory-with Story' (quoted in Pulpan and Rumbolt, 2008, p. 214).

The second strand (ribosome) is the narrative of connections, the ribosome strand that assembles Aboriginal and non-Aboriginal Stories. The second strand contains binding sites so connecting sections to Stories can aggregate. Somers (1999) states, 'Storytelling or narratives are a non-linear phenomenon, and can be seen as "networks of patterned relationships connected and config-ured over time and space"' (quoted in Lloyd et al., 2010, p. 712). The viewer/listener connects to the Stories in their own way, delving into their own Story of correlation, in relationship to the Story being told. The connecting narratives create a function to build a structure of connections/binding sites to the Mother.

This strand also holds the soma or is the body that contains the ribosomes that acts to transverse and translate Stories at the connection sites of attachment. The narrative approach holds and locates Ancestors into the centre of the process, with the Ancients being integral in attempting to generate, express and interpret meaning in a 
cross-cultural context. Identifying conjunction points for meaning to occur is through revealing Stories that all people hold within our being. The Stories are within the body, "Our memories are held in our hearts" (Harrison 2012, personal teaching) and not in our mind. It is the similarities within the Story identified within each person's heart that attaches to the points of relatedness not necessarily the intellectual memory. Oyler 's (2001) review of Sewall's (1998) work on narrative describes how 'the power of Story is to join people in space, time, identity, and role' (p. 79). It is important to note that a holistic examination is required with the term 'joining', to include all the entities that make up, and are Country (Rain, Rocks, Rivers, Ridges and so on).

The third line to the helix is the non-Aboriginal strand including colonisation and importantly its acceptance from an Aboriginal standpoint, as it all contributes to the holism and oneness approach. Colonisation has happened, is happening and is part of the Story. The third strand has a role in a biological fission, where it can replicate a Story of Country within their own spirit body to build non-Aboriginal peoples capacity to have a respectful relationship with Country. The key action is within the western body, not just the intellect, accepting the continuous replicated Yuin Story(ies) from a Mother into their own cell of understanding; accepting the side by side circular elements of similarities rather than maintaining the focus on the colonised Story of difference. The three strands interweave along the Story line to hold each strand together in conjoining facets of connection so it can all come together. Each strand safeguards each other to place, (Country), in the enactment of the replication in the legacies of the Ancestors. The Ancestors legacies of this Country and the 'others' Countries, through people's own Stories of embodiment and experiences contribute to the three-strand helix.

The third strand is instilled with the healing of spirit, acceptance and forgiveness, that it also involves Aboriginal and non-Aboriginal people. As Uncle Max (2009) states, 'it's a pretty big call to forgive... Forgiveness is for your healing. It's your self-healing, it's got nothing to do with the person that has probably done wrong' (p. 151). Forgiveness has a major role in human survival and the survival of the places where we live. 'I want to keep surviving so that I can embrace a lot of our culture and a lot of our knowledge' (Harrison 2009, p. 156). The acceptance of knowing in forgiveness from Aboriginal and non-Aboriginal people opens the spiritual door for the connecting cultural traits that exist. This strand enhances the cultural connections to come to the fore and replicate a 'place' with the Mother through the Stories of where you stand. This strand interweaving with the other strands crafts accepting footholds so ancestral bridges can be constructed and crossed. The legacy pedagogy is then allowed to 'kick in' 
through other processes that coincide with and in the Stories. The affirmation of the non-dialectal learning is bought to the surface with a dialectical influence through the sharing of the learning to each other through creative structures and yarnings.

The essence of time in building the relationship is substantial; this is because the relationship may not form in a person's lifetime in human form. This has to be accepted just as the Yuin Stories must be accepted; contributing to the search of conjunctions in Stories. Congruently the placement of the Yuin Cultural Aboriginal voice into a position of value will inspire indirectly or directly a re-culturalisation of knowing. This demands a non-Aboriginal spiritual re-shifting back to their Ancients in connection to ours in order to balance the imposed colonial chronological Stories wrapped over Country. This requires all peoples to look at self when their ancestors lived with the land in reliance not rebelliousness to their own Mother. This process accentuates the valuing of Yuin Stories. As Somerville et al. (2010) states, 'in using narrative we can move beyond simply telling Stories of hardship we can move into a space where Indigenous knowledges are valued' (p. 100). By using a continued privileging of our Yuin voices as both communication and strength we find a niche that can be shared by others who know how to be in our space.

Not everybody is prepared or ready to walk on Country to watch, listen and see the Stories laid out. Importantly the underlying currents of spirit from Yuin Stories are flowing and at times spilling out onto the 'economic flood plains'. This is paramount to plant seeds of 'belonging behaviour' with the Mother to move, immerse and 'cleanse' mindsets of cultural chasms to enable connections. The challenges to the enablement are anger, mistrust, ego, greed, religion and power, all of which are very hard surfaces to infiltrate for healing and acceptance to take place. Therefore patience is how we encourage people to the cleansing ceremony and the initiating step into awareness and understanding of Tripartation. Patience is a place where the mindset is prepared for spiritual adjustment to allow for conjunction points to take root in the body. From patience the listeners and tellers of the Stories find Stories that parallel and amalgamate. These Stories are then shared and cared for to inform respectful relationships in partnerships. This can produced emotional pinpoints of connectivity in subjective experiences, and these, when formed, can encourage the examination of similarities in cultural Stories. Mingadhuga Mingayung stimulates responsibilities of Tripartation in respectful relationship within the human body and spirit to Country, and Country to itself (human) through a Story. This is a completion of a circular journey of Story, started and continued by Country, that goes all the way around with 'others' to finish 
(another starting point) with a connection of oneness to the same Story so it is held by Country.

\section{Mingadhuga Mingayung}

Seeing Country teaches people how to hear with their eyes and to be 'regenerative learners'. Seeing the 'now' is important because we can learn to 'know' what has happened, what is happening in the living present and what will occur. While western dualistic framework tends to separate, for Yuin people the past, present and future is all the same thing. As Kwaymullina (2005) states, 'This country is a living Story... In the learning borne of country is the light that nourishes the world; and if country and the world is to be helped now, it is this light that must shine the way home' (quoted in Grieves, 2009, p. 31). Grandfather Sun provides the light for the nourishment of Yuin Country to show people how to heal the western 'progressive' thought that has disrupted our sight. 'Decolonising' and re-culturalising western 'progressive thought' (human/male centred) through listening to Mother Earth has the potential to liberate people from colonial intrusions on Aboriginal knowledge, ways of knowing and learning. As Battiste (2002) argues:

Knowledge teaches people how to be responsible for their own lives, develops their sense of relationships to others, and helps them model competent and respectful behaviour. Traditions, ceremonies, and daily observations are all integral parts of the learning process. They are spiritconnecting processes that enable gifts, visions, and spirits to emerge in each person (p. 14-15).

Mingadhuga Mingayung is how I hold my understandings of the teachings from Country in regards to sharing culture and heritage (with permission from Uncle Max). Mingadhuga Mingayung is saturated by the Ancients' legacy(s) of Yuin Country that respects the Ancients. This has informed Yuin ways of Learning over thousands of years: Watching, Listening and Seeing. Mingadhuga Mingayung guides non-Aboriginal peoples' understanding of the Yuin Ancients' teachings through Country that is at the Core of existence in oneness.

It is important not to separate the Ancients from the Mingadhuga Mingayung approach, pedagogy, process, outcome(s) and the individuals involved as it is all connected to Country. Mingadhuga Mingayung is the Story, place and space where the Yuin Elders and Story holders knowingly share the gifts of Gulaga (Mingadhuga 
Mingayung- one in the same). Imperatively the particular part of Country in which the teachings takes place(s) is the 'source' of the Story/knowledge and is the principal teacher. Country is a communicative current that can transmit Yuin ways of knowing and learning to non-Aboriginal people that have an open mind (space). The participants engaged in Yuin knowing, learning and behaving processes are guided by Elders of Country to enhance the possibility of feeling and seeing the Stories and spirit of Yuin Country. A purpose of the Stories is to initiate a reciprocal respectful relationship of taking care of Country, including the spirit of Country into what we do in our daily lives in the capacity of who we are. The approach is not about 'making' non-Aboriginal people, Aboriginal; it is a process of providing a guiding platform so a respectful (which must include reciprocity) relationship with Country occurs in Tripartation. It is imperative to note that Tipartation is not a duality of difference but a flow of connectivity. A function of Tripartation for non-Aboriginal peoples is to find connections, like any relationship, through their own entwined journey in what Country requires in a respectful and spiritual reciprocal relationship.

Country will share particular Stories with unseen and seen energies to activate sight and learning, triggering within the non-Aboriginal person reciprocated Stories of connection for learning to occur in respectful relationship. This relationship finds paralleling similarities from one another's Stories in relationship with Country being Mother Earth, Father Sky, Grandmother Moon and Grandfather Sun. There are many similarities in how cultures view these principal family members and this is how we initiate, reveal and show Tripartation. You learn from your Mother, Father, Grandmother and Grandfather about what is important. For this reason while on Yuin Country (home), and after learning Stories on/about Yuin Country (as in any relationship) you value and respect Yuin Country, not another Country's (home) perspective.

To engage with/in Mingadhuga Mingayung is the choice of non-Aboriginal people and the start of respectful relationships between Aboriginal and non-Aboriginal people. These respectful relationships are fostered by seeking and being invited by Elders to respect Country and being/becoming a community member in the family of Country. Significantly, it is not constituted by an organisation meeting western policy requirements. Mingadhuga Mingayung is non-Aboriginal people being taught by Country to understand and behave through the weave of their own Stories that they hold within themselves to connect to Country and, in turn, to self. Mingadhuga Mingayung replaces the western duality slash (to parallel) to demonstrate knowing 
Country as self and self as Country; then respect, responsibilities, reciprocity and relationships will develop if Country is at the Core of decisions made in respectful relationship. Aboriginal cultural knowing, learning and behaving in our way of 'there are always two in existence' act in parallel to find conjunction points (the third connecting fold of Tripartation) to reduce the damaging influence of the colonial dualisms that have been forced upon Yuin Country.

\section{Conclusion}

The colonisation of Country is the colonisation of self, therefore re-culturalisation and decolonisation is a process for everyone, and thus everyone can participate. The relationship(s) that are necessary have to be with non-Aboriginal peoples as nonAboriginal people/organisations/institutions are instrumental in the maintenance of the western duality. Tripartation provides a place and space for spirit to shine within the duality through Yuin Stories, so self can connect to the Stories of Country. The challenges and tensions of Tripartation is shifting the emphasis and absolute reliance on western theory, so Stories of Country can sit alongside and parallel with each other to help in the protection of the Mother. The western cultural observation lens portrays each 'other' as different; this must be re-focused to a lens of similarities, with difference maintaining a relationship of learning in connection with the Mother.

How we as Aboriginal people voice our Culture is how we show respect to the Mother that provides our voice. From my Aboriginal standpoint enhancing the capacity for Mother Earth's own voice to be heard by Australian organisations/institutions goes beyond western Cultural Awareness. It is individuals forming respectful relationships with Country and its people. If non-Aboriginal people start thinking about what a relationship with Country 'looks' like, Mingadhuga Mingayung will guide their sight to listen to Mother's voice. The most important initial step for Country (us) is nonAboriginal people moving outside the western dualistic mindset with an open mind to form a relationship with Country and Aboriginal people as Country. These steps into a unknown space of knowing create an opportunity for the foundation of a 'counterpoise' (two-way approach to 'closing the gap') approach to identify a 'meeting place' (a place for meetings and meeting place itself) away from the human focus over time. Mingdhuga Mingayung from my position is, in its simplest form: A 'Country' locus where Aboriginal people provide opportunities for non-Aboriginal people to experience and develop their own relationship with Country thereby creating a three-way relationship with Country connecting the Aboriginal and non-Aboriginal human others together within itself. 


\section{References}

Arichibald, J.-A. (2001). Editorial: Sharing aboriginal knowledge and aboriginal ways of knowing. Canadian Journal of Native Education 25, 1-5.

Battiste, M. (2002). Indigenous Knowledge and pedagogy in First Nations Education: A Literature Review with Recommendations. National Working Group on Education and the Minister of Indian Affairs. Indian and Northern Affairs, Ottawa, Canada. Retrieved fromhttp://www.afn.ca/uploads/files/education/24._2002_oct_marie_battiste_indigeno usknowledgeandpedagogy_lit_review_for_min_working_group.pdf

Birrell, C. 2006. Meeting country : deep engagement with place and indigenous culture. $\mathrm{PhD}$, University of Western Sydney.

Black, C. 2011. Maturing Australia through Australian Aboriginal Narrative Law. South Atlantic Quarterly, 110, 347-362.

Freire, P. (2000). Pedagogy of the oppressed, New York, Continuum.

Grieves, V. (2009). Aboriginal spirituality: Aboriginal philosophy, the basis of Aboriginal social and emotional wellbeing, Casuarina, N. T, Cooperative Research Centre for Aboriginal Health.

Harrison, M. D. \& McConchie, P. (2009). My people's Dreaming: an Aboriginal elder speaks on life, land, spirit and forgiveness, Warriewood, N.S.W, Finch Publishing.

Levinas, E. (2006). Entre nous: thinking of the other., Continuum International Publishing Group.

Lloyd, K., Suchet-Pearson, S., Wright, S. \& Burarrwanga, L. L. (2010). Stories of crossings and connections from Bawaka, North East Arnhem Land, Australia. Social \& Cultural Geography, 11, 701-717.

Oyler, C. (2001). Extending Narrative Inquiry. Malden: Blackwell Publishers.

Porr, M. \& Bell, H. R. (2012). Rock-art', 'Animism' and Two-way Thinking: Towards a Complementary Epistemology in the Understanding of Material Culture and 'Rock-art' of Hunting and Gathering People. Journal of Archaeological Method and Theory, 19, 161205.

Plumwood, V. (ed.) (2002). Environmental Culture: The ecological crisis of reason. Routledge: Taylor \& Francis Group, London and New York.

Pulpan A. \& Rumbolt, M. (2008). Stories of Resurfacing: The University and Aboriginal Knowledge. Canadian Journal of Native Education, 31, 214-322.

Rose D, James D and Watson C [2003] Indigenous Kinship with the Natural World in NSW, New South Wales, National Parks and Wildlife Service.

Somerville, C., Somerville, K. \& Wyld, F. (2010). Martu Storytellers : Aboriginal narratives within the academy. Australian Journal of Indigenous Education, 39, 96-101 